\title{
Geology
}

\section{Slab breakoff as a mechanism for flipping of subduction polarity in Taiwan}

\author{
Louis S. Teng, C. T. Lee, Y. B. Tsai and Li-Yuan Hsiao
}

Geology 2000;28;155-158

doi: 10.1130/0091-7613(2000)28<155:SBAAMF>2.0.CO;2

Email alerting services

Subscribe

Permission request click www.gsapubs.org/cgi/alerts to receive free e-mail alerts when new articles cite this article

click www.gsapubs.org/subscriptions/ to subscribe to Geology

click http://www.geosociety.org/pubs/copyrt.htm\#gsa to contact GSA

Copyright not claimed on content prepared wholly by U.S. government employees within scope of their employment. Individual scientists are hereby granted permission, without fees or further requests to GSA, to use a single figure, a single table, and/or a brief paragraph of text in subsequent works and to make unlimited copies of items in GSA's journals for noncommercial use in classrooms to further education and science. This file may not be posted to any Web site, but authors may post the abstracts only of their articles on their own or their organization's Web site providing the posting includes a reference to the article's full citation. GSA provides this and other forums for the presentation of diverse opinions and positions by scientists worldwide, regardless of their race, citizenship, gender, religion, or political viewpoint. Opinions presented in this publication do not reflect official positions of the Society.

\section{Notes}

THE 


\title{
Slab breakoff as a mechanism for flipping of subduction polarity
}

\section{in Taiwan}

\author{
Louis S. Teng* Institute of Geophysics and Planetary Physics, University of California, Los Angeles, California 90095-1567, USA \\ C. T. Lee
Y. B. Tsai \\ Li-Yuan Hsiao Department of Geological and Environmental Sciences, Stanford University, Stanford, California 94305-2115, USA
}

\begin{abstract}
We propose a model that involves breakoff of the east-dipping Eurasian slab beneath the Taiwan orogen to account for the flipping of subduction polarity in northern Taiwan. The breakoff was initiated in southern Ryukyu in the early Pliocene and then propagated southwestward into Taiwan, like an opening zipper. Detachment of the Eurasian slab has created a mantle window for the north-dipping Philippine Sea plate to move in laterally, causing a switch in the subduction polarity. Slab breakoff not only provides a testable model for the lithospheric structure of Taiwan, but also accounts for the high heat flow, rapid uplift, synorogenic extension, deepfocus earthquakes, and north-diminishing crustal contraction in the Taiwan mountain belt.
\end{abstract}

Keywords: tectonics, lithospheric structure, subduction, collision, Taiwan.

\section{INTRODUCTION}

Formed by the collision between the Luzon arc and the China continent (Chai, 1972), the active Taiwan mountain belt has often been used as a classic example for illustrating mountain building processes (e.g., Barr and Dahlen, 1989; Chemenda et al., 1997; Suppe, 1981; Wu et al., 1997). Despite the fact that most of the Taiwan orogen is still being pushed up by the collision, the northeast part of the orogen has evolved beyond the collisional phase and is in the process of collapsing (Teng, 1996). The transition from orogenic buildup to orogenic collapse is associated with the flipping of subduction polarity from northwest facing in southern Taiwan to southeast facing in northeast Taiwan (Fig. 1).

Although long recognized as an important tectonic feature in Taiwan (Chai, 1972; Suppe, 1984; Tsai, 1986), the flipping of subduction polarity has not been fully investigated. Suppe (1984) hypothesized that the flipping of subduction polarity might have propagated from Ryukyu to Taiwan but did not address the flipping mechanism. Various tectonic features have been related to the polarity change in northern Taiwan (e.g., Chemenda et al., 1997; Kao et al., 1998; Lee and Wang, 1988; Ma et al., 1996; Rau and Wu, 1995; Roecker et al., 1987; Teng, 1996; Teng et al., 1992; Tsai, 1986; Wu et al., 1997; Yen et al., 1998), but how the polarity switched has not been elucidated. On the basis of integrated geologic and geophysical information, we demonstrate that the east-dipping Eurasian slab may be breaking off, like an opening zipper, beneath the Taiwan orogen. We propose that slab breakoff created a mantle window for the north-dipping Philippine Sea plate to

*Present address: Institute of Geology, National Taiwan University, 245 Choushan Road, Taipei, Taiwan, Republic of China. E-mail: teng@ @un03.gl.ntu.edu.tw. fill in laterally, which has caused flipping of subduction polarity in southern Ryukyu and northern Taiwan since the early Pliocene.

\section{TECTONIC BACKGROUND}

The Taiwan mountain belt is located on the boundary between the Eurasian plate and the Teng et al. (1992), and Yang et al. (1996).
Philippine Sea plate (Fig. 1). The Philippine Sea plate has been moving in a north to northwest direction since early Tertiary time (Hall et al., 1995; Seno et al., 1993), subducting beneath the Eurasian plate north of Taiwan but overriding the Eurasian plate to the south. Convergence between the two plates has generated the southeast-facing Ryukyu arc in the north and the northwest-facing Luzon arc in the south. Taiwan is in the transfer zone between the two opposite-facing arcs.

In the Miocene, prior to the collision, the Luzon arc was located more than $500 \mathrm{~km}$ southeast of its present position and had been moving north-northwestward with the Philippine Sea plate (Teng, 1990). The Ryukyu arc was situated northeast of the island Ishigaki-Jima, and the western edge of the subducting Philippine Sea plate was located along a line trending north-northwest in southern Ryukyu (PWEP in Fig. 1). The area southwest of

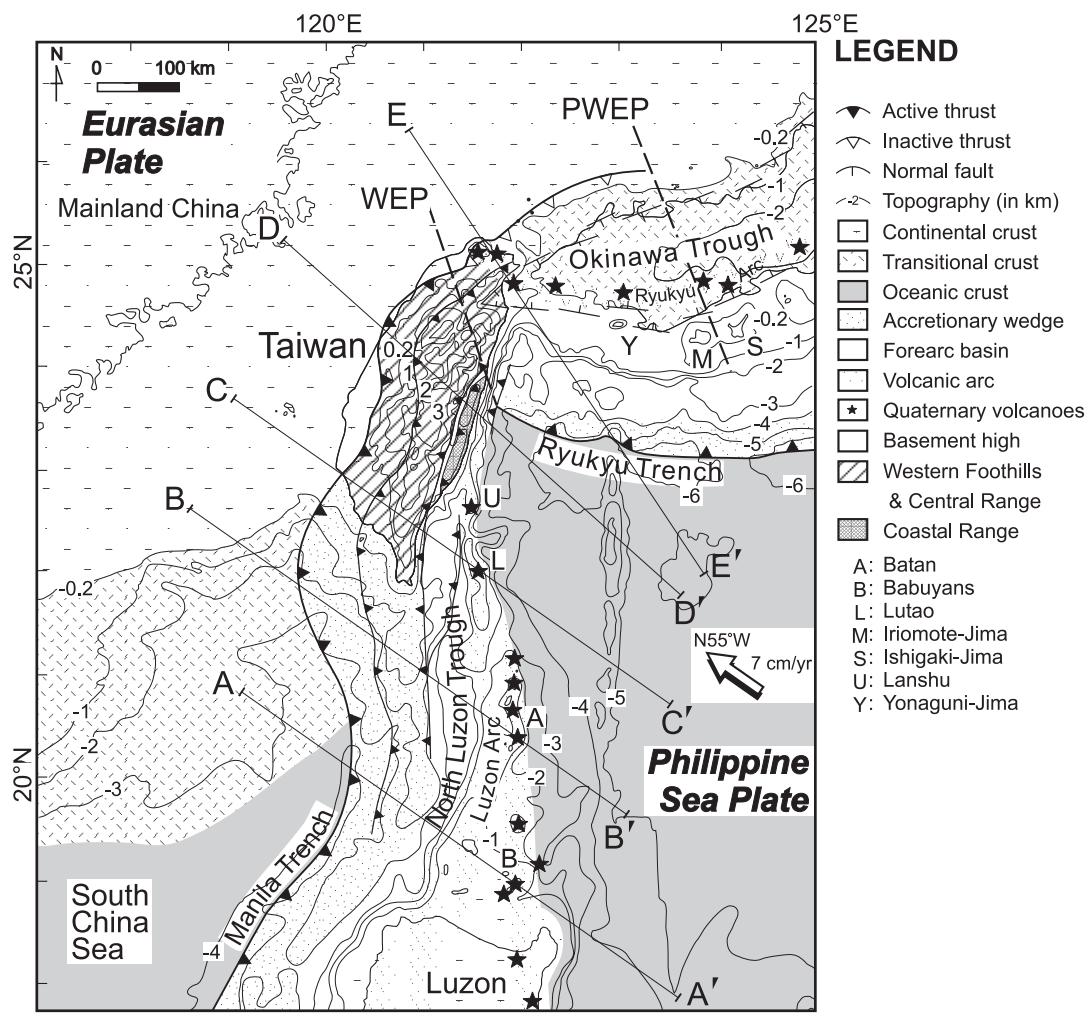

Figure 1. Plate tectonic setting of Taiwan. PWEP_-precollision position of WEP;WEPsurface projection of western edge of north-dipping Philippine Sea plate. Summarized from Hayes and Lewis (1984), Lewis and Hayes (1989), Liu et al. (1997), Lundberg et al. (1997), Seno et al. (1993), Sibuet et al. (1998), Taylor and Hayes (1983), Teng (1990, 1996), 
this line, including Taiwan and part of southern Ryukyu, was occupied by the passive China continental margin, which extended to the northern flank of the South China Sea. The north-trending Luzon arc approached the northeast-trending China continental margin obliquely, and the northern end of the arc collided with the continental margin of southern Ryukyu in late Miocene time. The collision deformed the outer China continental margin and the northern Luzon arc and incorporated both into the collision orogen. In the early Pliocene, the Philippine Sea plate changed its motion to northwestward and the Luzon arc began to override the continental margin more rapidly. The collision propagated southwestward and pushed the orogen to migrate from southern Ryukyu into Taiwan. In the meantime, the northdipping Philippine Sea plate beneath the Ryukyu arc also moved westward, and its west margin progressively advanced to its present position in northeast Taiwan (WEP in Fig. 1). As the northdipping Philippine Sea plate moved underneath the northern part of the collision orogen, the polarity of subduction flipped, and the overlying orogen became incorporated into the Ryukyu arc (Teng, 1996). The process of subduction, collision, and flipping of subduction is still under way in the Taiwan area.

Owing to the oblique nature of the collision, the variation in the contemporary tectonics along the plate boundary from Luzon to Taiwan demonstrates the sequential tectonic developments leading to the flipping of subduction polarity (Fig. 2). South of Taiwan, the Eurasian plate is actively subducting eastward beneath the Luzon arc, the oceanic lithosphere of the South China Sea and transitional lithosphere of the China continental slope sequentially going down into the Luzon subduction zone (sections $\mathrm{A}-\mathrm{A}^{\prime}$ and $\mathrm{B}-\mathrm{B}^{\prime}$ ). In southern Taiwan, drastic collision commences, and the accretionary wedge emerges above the sea level as the continental lithosphere is pulled down into the subduction zone (section $\mathrm{C}-\mathrm{C}^{\prime}$ ). In central Taiwan, the continental lithosphere continues to subduct eastward, and the collision orogen grows to its maximum height (section D-D'). However, neither arc volcanism nor deep earthquakes have been observed, hence, the plate interaction remains obscure beneath the collision orogen. In northeastern Taiwan, the subduction polarity has flipped, and the Philippine Sea plate is underthrusting the Eurasian plate (section E-E'). The orogen, no longer subjected to collision, is under the influence of lithospheric stretching and Ryukyu arc magmatism.

As far as the deep lithospheric structure is concerned, it is clear that the east-dipping Eurasian slab beneath the Luzon arc system extends from Luzon to southern Taiwan without a significant break (sections A-A' to C-C' of Fig. 2; Hamburger et al., 1983). The north-dipping Philippine Sea plate beneath the Ryukyu arc also extends continuously from southern Ryukyu to northeast Tai-

Figure 2. Plate interactions in Luzon-Taiwan region. Symbols and locations are shown in Figure 1. EP-Eurasian plate; PSP-Philippine Sea plate. Open dots denote earthquakes of $\mathrm{Mb} \geq 4$ in $50 \mathrm{~km}$ swath projected onto section. Synthesized from Hamburger et al. (1983), Hayes and Lewis (1984), Kao et al. (1998), Lewis and Hayes (1989), Louden (1980), Ma (1987), Nissen et al. (1995), Oda and Senna (1994), Rau and Wu (1995), Taylor and Hayes (1983), Tsai (1986), Wu et al. (1997), and Yang et al. (1996). Earthquake data are from National Earthquake Information Center of U.S. Geological Survey.

wan (section E-E'; Kao et al., 1998). Bracketed by these two well-defined subduction zones, the east-dipping Eurasian slab must be somehow transformed into the north-dipping Philippine Sea slab beneath north-central Taiwan, i.e., beneath the area between the western edge of the Philippine Sea slab (WEP, Fig. 1) and section C-C'

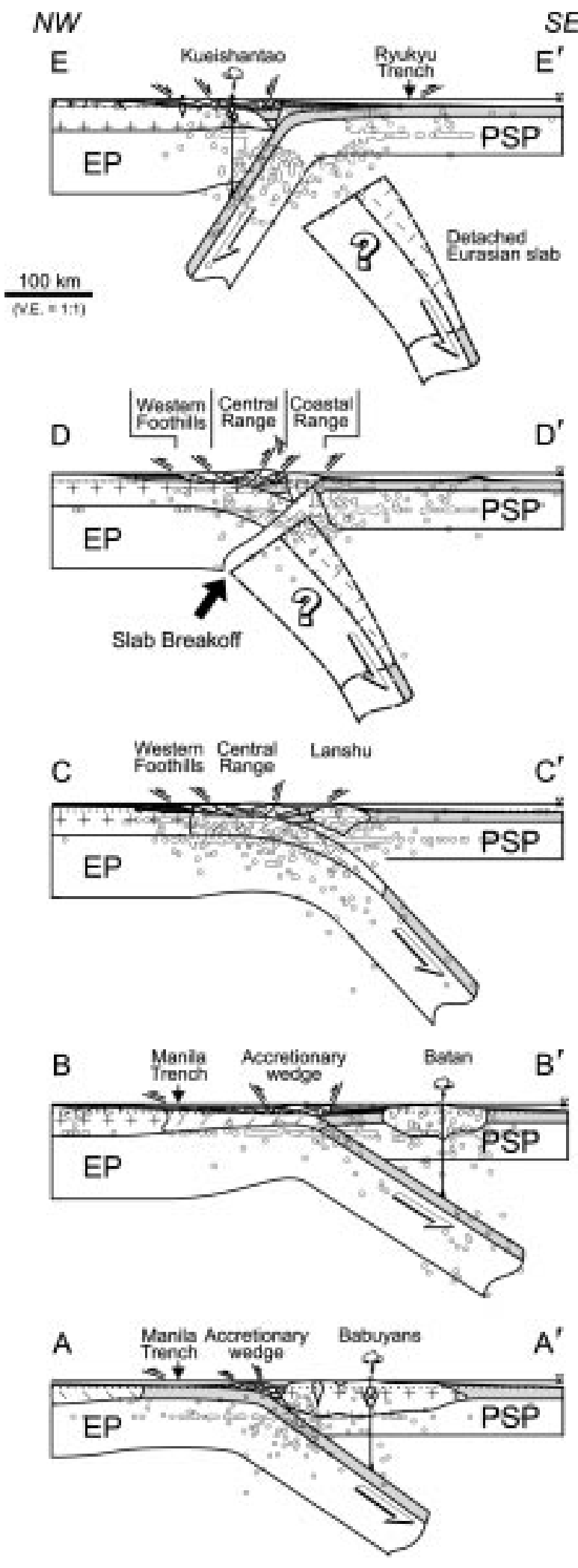

(Fig. 1). However, owing to the lack of a clear picture about the deep-mantle structure of Taiwan, how the transformation takes place is not clear.

\section{PALEOTECTONIC CONSIDERATIONS}

Although geophysical evidence might be insufficient to delineate the plate configuration be- 
neath Taiwan, geologic records seem to indicate that the east-dipping Eurasian slab exists beneath north-central Taiwan and southern Ryukyu. Both southern Ryukyu and Taiwan were part of the passive continental margin of the South China Sea before being deformed by the collision. The precollision tectonic configuration of this deformed margin, based on stratigraphic and structural reconstruction, was very similar to that of the present northern margin of the South China Sea (Teng, 1992). The margin most likely encompassed a continental lithosphere, a transitional lithosphere, and a certain length of oceanic lithosphere, as does the present South China Sea margin west of the Luzon arc (Fig. 1). In Miocene time, hundreds of kilometers of the oceanic lithosphere must have been subducted beneath the Luzon arc in order to generate the voluminous Miocene arc volcanic rocks in the Coastal Range of eastern Taiwan. Pieces of the consumed oceanic lithosphere were scraped off during the subduction and emplaced as ophiolitic blocks in the melange deposits of the Coastal Range (Suppe et al., 1981). The precollision scenario of southern Ryukyu and northeast Taiwan was probably not much different from that of the present LuzonBabuyan region (section A-A' in Fig. 2). Later in Pliocene-Quaternary time, the oceanic lithosphere, transitional lithosphere, and part of the continental lithosphere may have been successively subducted in the way shown in the present LuzonTaiwan area (sections A-A' to D-D'). Hence it is very likely that the downgoing Eurasian slab beneath the Luzon arc extends all the way from Luzon north to southern Ryukyu. However, this scenario would create a dilemma of having two intersecting slabs beneath northeast Taiwan and southern Ryukyu, because the north-dipping Philippine Sea plate is also there.

The most likely solution to this dilemma is to have the deeper part of the downgoing Eurasian slab break off and sink into the deep mantle so that a window could be created for the north-dipping Philippine Sea slab. If this interpretation is correct, the breakoff should have been initiated in southern Ryukyu (near PWEP in Fig. 1), where the north-dipping Philippine Sea plate began its westward advance in the early Pliocene. It proceeded like an opening zipper, propagating from southern Ryukyu into Taiwan and leaving a mantle window for the west-advancing Philippine Sea plate. The western edge of the north-dipping Philippine Sea plate has reached northeast Taiwan, so slab breakoff is probably taking place farther to the southwest (section D-D' in Fig. 2). Beneath northeast Taiwan and southern Ryukyu, the downgoing Eurasian slab may have already detached from its overlying counterpart and may be sinking under the Philippine Sea plate (section E-E').

\section{SLAB BREAKOFF}

From the dynamics point of view, slab breakoff in a collision setting like Taiwan is probably a corollary rather than a surprise. As pointed out by Davies and von Blanckenburg (1995), when a passive continental margin enters the subduction zone, the buoyant continental lithosphere resists subduction, whereas the forerunning oceanic lithosphere continues to go down into the mantle. This process generates an extensional force acting on the transitional lithosphere between, which increases in magnitude with increasing subduction and may eventually result in breakoff of the downgoing oceanic slab. This phenomenon has been reported from a comparable collision zone in Timor (McCaffrey et al., 1985) and several other places in the Mediterranean (Wortel and Spakman, 1992).

Despite the lack of sufficient data to demonstrate the complete lithospheric structure beneath Taiwan, seismic tomographic studies based on local-network data show that the upper mantle of central Taiwan is distinctively different from that of northern Taiwan (Roecker et al., 1987). In central Taiwan (south of lat $24^{\circ} \mathrm{N}$ ), the continental crust of the Eurasian plate is believed to be subducted to the depth of around $50 \mathrm{~km}$, as shown by a zone of low P-wave velocity. In northern Taiwan (north of lat $24^{\circ} \mathrm{N}$ ), the low-velocity zone becomes less distinct and is offset to the east by $25-30 \mathrm{~km}$. At about lat $24^{\circ} \mathrm{N}$, earthquakes line up in a narrow zone dipping eastward from the near surface in western Taiwan down to the depth of $80 \mathrm{~km}$. Although the focal mechanisms of shallow earthquakes exhibit horizontal compression consistent with the collision tectonism on the surface, those of the earthquakes deeper than $40 \mathrm{~km}$ show downdip extension (Lin and Roecker, 1993). These features seem to indicate that the Eurasian plate may still be a continuous slab beneath central Taiwan, but is in the process of breaking as a result of slab-parallel extension. Beneath northern Taiwan, however, the lower part of the Eurasian slab may have already broken off, and the resultant mantle window is probably widening toward the north.

Although difficult to verify, slab breakoff beneath Taiwan has some important consequences that can be scrutinized with data from observations. Slab breakoff inevitably induces asthenospheric upwelling that raises the geothermal gradient in the collision orogen and pushes the orogen to rise buoyantly. As a result, the heat flow and uplift rate would be high in the collision orogen, which has been well documented in the Taiwan orogen, especially in the Central Range (Barr and Dahlen, 1989; Chen, 1984). Breakoff also diminishes the downward slab pull that drives plate convergence and crustal shortening in the overlying orogen. Hence, the contractional deformation in the collision orogen may be reduced once the slab is breaking and may eventually be terminated if the slab completely breaks off. Geodetic data from a Global Positioning System survey show that the intensity of crustal shortening is high in southern Taiwan but progressively decreases to nearly zero in northern Taiwan (Yu et al., 1997), which agrees with what is expected if slab breakoff has begun in the north. In addition, with diminishing compressional support, the thermally uplifted orogen above the breaking slab may be subjected to crustal extension as a result of gravitational collapse. In central and northern Taiwan, synorogenic extension has been illustrated by widespread earthquakes of extensional focal mechanisms (Kao et al., 1998; Rau et al., 1996) and late-stage normal faulting (Crespi et al., 1996; Lee et al., 1997), which lends further support to the slab-breakoff hypothesis.

\section{DISCUSSION AND CONCLUSIONS}

The idea that slab breakoff occurs when the continental lithosphere enters the subduction zone was raised in the early years of studies of plate tectonics (McKenzie, 1969) and has been the subject of intense investigation (Davies and von Blanckenburg, 1995; Wortel and Spakman, 1992; Hildebrand and Bowring, 1999). Chai (1972) speculated that the Eurasian plate beneath Taiwan might have broken off, which caused buoyant uplift of the overlying continental lithosphere, upthrust of the Central Range, and generation of the imbricated folds and thrusts and gravitational nappes in western Taiwan. However, owing to the lack of solid supporting evidence, Chai's proposal was largely ignored in later tectonic studies (e.g., Barr and Dahlen, 1989; Chemenda et al., 1997; Roecker et al., 1987; Suppe, 1981, 1984; Teng, 1990; Tsai, 1986; Wu et al., 1997). As shown in this paper, geologic and geophysical observations made in the past 20 years are consistent with the notion that the Eurasian slab has broken off beneath southern Ryukyu and northern Taiwan and is in the process of breaking beneath central Taiwan. The breakoff first began in southern Ryukyu in the early Pliocene and has since propagated into Taiwan, like an opening zipper. Breakoff of the Eurasian slab creates a mantle window for the north-dipping Philippine Sea plate to fill in and has been responsible for flipping of subduction polarity in Taiwan.

As a hypothesis, slab breakoff provides not only a plausible model for the deep lithospheric structure of Taiwan, but also a viable connection between the Luzon and Ryukyu arcs. It successfully accounts for the high heat flow, rapid uplift, synorogenic extension, deep seismicity, and north-diminishing crustal contraction observed in the Taiwan mountain belt. It predicts that a detached Eurasian slab is beneath northern Taiwan and southern Ryukyu (section E-E'), which can be readily tested by future investigations. If further substantiated, the Taiwan mountain belt may offer another actualistic example for those ancient mountain belts that might have gone through the slab-breakoff process (e.g., Davies and von Blanckenburg, 1995; Hildebrand and Bowring, 1999). 


\section{ACKNOWLEDGMENTS}

We thank An Yin, Don Fisher, and Margaret Rusmore for constructive comments; National Science Council, Republic of China, and Institute of Geophysics and Planetary Physics, University of California, Los Angeles, for financial support.

\section{REFERENCES CITED}

Barr, T. D., and Dahlen, F. A., 1989, Brittle frictional mountain building: 2 . Thermal structure and heat budget: Journal of Geophysical Research, v. 94, p. 3923-3947.

Chai, B. H. T., 1972, Structure and tectonic evolution of Taiwan: American Journal of Science, v. 272, p. 389-422.

Chemenda, A. I., Yang, R. K., Hsieh, C. H., and Groholsky, A. L., 1997, Evolutionary model for the Taiwan collision based on physical modelling: Tectonophysics, v. 274, p. 253-274.

Chen, Hueyfen, 1984, Crustal uplift and subsidence in Taiwan: An account based upon retriangulation results: Republic of China, Central Geological Survey Special Publication no. 3, p. 127-140.

Crespi, J., Chan, Y. C., and Swaim, M., 1996, Synorogenic extension and exhumation of the Taiwan hinterland: Geology, v. 24, p. 247-250.

Davies, J. H., and von Blanckenburg, F., 1995, Slab breakoff: A model of lithosphere detachment and its test in the magmatism and deformation of collisional orogens: Earth and Planetary Science Letters, v. 129, p. 85-102.

Hall, R., Ali, J. R., Anderson, C. D., and Baker, S. J., 1995, Origin and motion history of the Philippine Sea plate: Tectonophysics, v. 251, p. 229-250.

Hamburger, M. W., Cardwell, R. K., and Isacks, B. L., 1983, Seismotectonics of the northern Philippine island arc, in Hayes, D. E., ed., The tectonic and geologic evolution of Southeast Asian seas and islands, Part 2: American Geophysical Union Geophysical Monograph 27, p. 1-22.

Hayes, D. E., and Lewis, S. D., 1984, A geophysical study of the Manila Trench, Luzon, Philippines: 1. Crustal structure, gravity, and regional tectonic evolution: Journal of Geophysical Research, v. 89, p. 9171-9195.

Hildebrand, R. S., and Bowring, S. A., 1999, Crustal recycling by slab failure: Geology, v. 27, p. 11-14.

Kao, H., Shen, S. J., and Ma, K. F., 1998, Transition from oblique subduction to collision: Earthquakes in the southernmost Ryukyu arc-Taiwan region: Journal of Geophysical Research, v. 103, p. 7211-7229.

Lee, C. T., and Wang, Y., 1988, Quaternary stress changes in northern Taiwan and their tectonic significance: Geological Society of China Proceedings, v. 31, p. 209-230.

Lee, J. C., Angelier, J., and Chu, H. T., 1997, Polyphase history and kinematics of a complex major fault zone in the northern Taiwan mountain belt: The Lishan fault: Tectonophysics, v. 274, p. 97-115.

Lewis, S. D., and Hayes, D. E., 1989, Plate convergence and deformation, north Luzon Ridge, Philippines: Tectonophysics, v. 168, p. 221-237.

Lin, C. H., and Roecker, S. W., 1993, Deep earthquakes beneath central Taiwan: Mantle shearing in an arccontinent collision: Tectonics, v. 12, p. 745-755.
Liu, C. S., Huang, I. L., and Teng, L. S., 1997, Structural features off southwest Taiwan: Marine Geology, v. 137, p. 305-319.

Louden, K. E., 1980, The crustal and lithospheric thicknesses of the Philippine Sea as compared to the Pacific: Earth and Planetary Science Letters, v. 50 , p. $275-288$.

Lundberg, N., Reed, D. L., Liu, C. S., and Lieske, J., Jr., 1997, Forearc-basin closure and arc accretion in the submarine suture zone south of Taiwan: Tectonophysics, v. 274, p. 5-23.

Ma, K. F., Wang, J. H., and Zhao, D., 1996, Three-dimensional seismic velocity structure of the crust and uppermost mantle beneath Taiwan: Journal of Physical Earth, v. 44, p. 85-105.

Ma, X.-Y., 1987, Lithospheric dynamics map of China and adjacent seas (1:4000 000) and explanatory notes: Beijing, Geological Publishing House, 53 p.

McCaffrey, R., Molnar, P., Roecker, S., and Joyodiwiryo, Y., 1985, Microearthquake seismicity and fault plane solutions related to arc-continent collision in the eastern Sunda arc, Indonesia: Journal of Geophysical Research, v. 90, p. 4511-4528.

McKenzie, D. P., 1969, Speculations on the consequences and causes of plate tectonics: Royal Astronomical Society Geophysical Journal, v. 18, p. $1-32$.

Nissen, S. S., Hayes, D. E., Yao, B., Zeng, W., Chen, Y., and Nu, X., 1995, Gravity, heat flow, and seismic constraints on the process of crustal extension: Northern margin of the South China Sea: Journal of Geophysical Research, v. 100, p. 22,447-22,483.

Oda, H., and Senna, N., 1994, Regional variation in surface wave group velocities in the Philippine Sea: Tectonophysics, v. 233, p. 265-277.

Rau, R. J., and Wu, F. T., 1995, Tomographic imaging of lithospheric structures under Taiwan: Earth and Planetary Science Letters, v. 133, p. 517-532.

Rau, R. J., Wu, F. T., and Shin, T. C., 1996, Regional network focal mechanism determination using $3 \mathrm{D}$ velocity model and $S H / P$ amplitude ratio: Seismological Society of America Bulletin, v. 86, p. 1270-1283.

Roecker, S. W., Yeh, Y. H., and Tsai, Y. B., 1987, Three-dimensional $\mathrm{P}$ and $\mathrm{S}$ wave velocity structures beneath Taiwan: Deep structure beneath an arc-continent collision: Journal of Geophysical Research, v. 92 , p. 10,547-10,570.

Seno, T., Stein, S., and Gripp, A. E., 1993, A model for the motion of the Philippine Sea plate consistent with NUVEL-1 and geological data: Journal of Geophysical Research, v. 98, p. 17,941-17,948.

Sibuet, J. C., Deffontaines, B., Hsu, S. K., Thereau, N., Le Formal, J. P., Liu, C. S., and ACT party, 1998, Okinawa trough backarc basin: Early tectonic and magmatic evolution: Journal of Geophysical Research, v. 103, p. 30,245-30,267.

Suppe, J., 1981, Mechanics of mountain building and metamorphism in Taiwan: Geological Society of China Memoir 4, p. 67-89.
Suppe, J., 1984, Kinematics of arc-continent collision, flipping of subduction, and backarc spreading near Taiwan, in Tsan, S. F., et al., eds., A special volume dedicated to Chun-Sun Ho on the occasion of his retirement: Geological Society of China Memoir 6, p. 21-33.

Suppe, J., Liou, J. G., and Ernst, W. G., 1981, Paleogeographic origins of the Miocene East Taiwan ophiolite: American Journal of Science, v. 281, p. 228-246.

Taylor, B., and Hayes, D. E., 1983, Origin and history of the South China Sea, in Hayes, D. E., ed., The tectonic and geologic evolution of Southeast Asian seas and islands, Part 2: American Geophysical Union Geophysical Monograph 27, p. 23-56.

Teng, L. S., 1990, Geotectonic evolution of late Cenozoic arc-continent collision in Taiwan: Tectonophysics, v. 183 , p. 67-76.

Teng, L. S., 1992, Geotectonic evolution of Tertiary continental margin basins of Taiwan: Petroleum Geology of Taiwan, no. 27, p. 1-19.

Teng, L. S., 1996, Extensional collapse of the northern Taiwan mountain belt: Geology, v. 24, p. 949-952.

Teng, L. S., Chen, C. H., Wang, W. S., Liu, T. K., Juang, W. S., and Chen, J. C., 1992, Plate kinematic model for late Cenozoic arc magmatism in northern Taiwan: Geological Society of China Journal, v. 35, p. 1-18.

Tsai, Y. B., 1986, Seismotectonics of Taiwan: Tectonophysics, v. 125, p. 17-37.

Wortel, M. J. R., and Spakman, W., 1992, Structure and dynamics of subducted lithosphere in the Mediterranean region: Verhandelingen van het Koninklijke Nederlandse Akademie van Wetenschappen, v. 95, p. 325-347.

Wu, F. T., Rau, R. J., and Salzberg, D., 1997, Taiwan orogeny: Thin-skinned or lithospheric collision: Tectonophysics, v. 274, p. 85-101.

Yang, T. F., Lee, T. F., Chen, C. H., Cheng, S. N., Knittel, U., Punongbayan, R. S., and Rasda, A. R., 1996, A double island arc between Taiwan and Luzon: Consequence of ridge subduction: Tectonophysics, v. 258, p. 85-101.

Yen, H. Y., Yeh, Y. H., and Wu, F. T., 1998, Two-dimensional crustal structures of Taiwan from gravity data: Tectonics, v. 17, p. 104-111.

Yu, S. B., Chen, H. Y., and Kuo, L. C., 1997, Velocity field of GPS stations in the Taiwan area: Tectonophysics, v. 274, p. 41-59.

Manuscript received July 27, 1999

Revised manuscript received October 20, 1999

Manuscript accepted October 29, 1999 